\title{
Meaning of aging for caregivers of senile elderly people
}

\author{
Significado do envelhecimento para cuidadores de idosos senis \\ Significado del envejecimiento para cuidadores de ancianos seniles
}

Sara Ingrid de Rezende Ferreira'
ORCID: 0000-0001-8250-5616

Elen Ferraz Teston'

ORCID: 0000-0001-6835-0574

Sonia Silva Marcon"

ORCID: 0000-0002-6607-362X

Bianca Cristina Ciccone Giacon-Arruda' ORCID: 0000-0002-8433-6008

Juliete Bispo dos Santos Mandu' ORCID: 0000-0002-6883-1391

Josiel Elisandro Werle' ORCID: 0000-0001-7679-4335

Sueli Aparecida Frari Galera"' ORCID: 0000-0001-7974-9214

'Universidade Federal de Mato Grosso do Sul. Campo Grande, Mato Grosso do Sul, Brazil.

"Universidade Estadual do Paraná. Maringá, Paraná, Brazil.

I'Universidade de São Paulo. Ribeirão Preto, São Paulo, Brazil

How to cite this article: Ferreira SIR, Teston EF, Marcon SS, Giacon-Arruda BCC, Mandu JBS, Werle JE, et al. Meaning of aging for caregivers of senile elderly people.

Rev Bras Enferm. 2021;74(4):e20201240.

https://doi.org/10.1590/0034-7167-2020-1240

\section{Corresponding author:}

Elen Ferraz Teston

E-mail: elen-1208@hotmail.com

EDITOR IN CHIEF: Antonio José de Almeida Filho ASSOCIATE EDITOR: Ana Fátima Fernandes

\section{ABSTRACT}

Objectives: to understand the meaning of aging for caregivers of senile elderly people. Methods: qualitative study carried out with 12 caregivers of elderly people registered in the Home Care Service, adopting the Explanatory Model of Kleinman's Disease as a theoretical framework. Data were collected from April to June 2019, through semi-structured, audio-recorded interviews, carried out at home and submitted to content analysis. Results: taking care of senile elderly people triggers reflections on aging that sometimes lead to a new meaning of this process, besides stimulating the recognition of the factors that influence it, with emphasis on the life history, occupation and deleterious behaviors adopted throughout life. Final Considerations: the care experience influences the meaning attributed to aging, favoring: the identification of modifiable and non-modifiable aspects and behaviors that make it healthy; reflection on aging itself, with a new meaning of habits and behaviors to be adopted.

Descriptors: Caregiver; Elderly; Aging; Nursing; Home Care.

\section{RESUMO}

Objetivos: compreender o significado do envelhecimento para cuidadores de idosos senis. Métodos: estudo qualitativo realizado com 12 cuidadores de idosos cadastrados no Serviço de Atenção Domiciliar, adotando-se o Modelo Explicativo de Doença de Kleinman como referencial teórico. Os dados foram coletados no período de abril a junho de 2019, mediante entrevistas semiestruturadas, audiogravadas, realizadas no domicílio e submetidas à análise de conteúdo. Resultados: cuidar de idoso senil desencadeia reflexões sobre o envelhecimento que por vezes levam à ressignificação desse processo, além de estimular o reconhecimento dos fatores que o influenciam, com destaque para a história de vida, ocupação e comportamentos deletérios adotados ao longo da vida. Considerações Finais: a experiência de cuidar influencia o significado atribuído ao envelhecimento, favorecendo: a identificação de aspectos e comportamentos modificáveis e não modificáveis que o tornam saudável; a reflexão sobre o próprio envelhecimento, com ressignificação de hábitos e comportamentos a serem adotados. Descritores: Cuidador; Idoso; Envelhecimento; Enfermagem; Assistência Domiciliar.

\section{RESUMEN}

Objetivos: comprender el significado del envejecimiento para cuidadores de ancianos seniles. Métodos: estudio cualitativo realizado con 12 cuidadores de ancianos registrados en Servicio de Atención Domiciliario, adoptándose el Modelo Explicativo de Enfermedad de Kleinman como referencial teórico. Datos recogidos en el período de abril a junio de 2019, mediante entrevistas semiestructuradas, audiograbadas, realizadas en el domicilio y sometidas al análisis de contenido. Resultados: cuidar de anciano senil desencadena reflexiones sobre el envejecimiento que por veces llevan a la resignificación de ese proceso, además de estimular el reconocimiento de factores que lo influencian, con destaque a la historia de vida, ocupación y comportamientos deletéreos adoptados al largo de la vida. Consideraciones Finales: experiencia de cuidar influencia el significado atribuido al envejecimiento, favoreciendo: la identificación de aspectos y comportamientos cambiables y no cambiables que lo vuelven saludable; la reflexión sobre el propio envejecimiento, con resignificación de hábitos y comportamientos a ser adoptados. Descriptores: Cuidador; Anciano; Envejecimiento; Enfermería; Asistencia Domiciliaria. 


\section{INTRODUCTION}

Aging is a natural stage of life, which implies gradual changes in the physiological system related to age ${ }^{(1)}$. This process is influenced by genetic factors and habits adopted throughout life, which can result in senile aging - the one accompanied by a disease with the potential to compromise the performance of everyday tasks due to physical and occupational limitations ${ }^{(2)}$.

In these conditions, to ensure the maintenance and continuity of human existence, especially in the home environment, the presence of a caregiver is essential ${ }^{(2)}$. It should be noted that this role can be played by formal caregivers (people with specific training); or informal (members of their own family or social network, who assist in carrying out basic daily activities, depending on the specifics of each case) $)^{(3)}$.

Studies carried out with caregivers, both in the national and international context, emphasize the negative impacts that this function has on the lives of those who assume it, with special emphasis on overload, as it directly impacts quality of life and physical and mental health ${ }^{(4-7)}$. The overload (physical, psychological and emotional experienced) can trigger stress and even personality changes, especially when associated with the financial overload resulting from the condition of illness in the family context ${ }^{(8-9)}$.

However, when assuming the role of caregiver (formal or informal) for a senile elderly person, it is possible for the person to be sensitive to the changes and limitations imposed by this condition, to reflect on the meanings attributed to his own life and to seek new knowledge, in order to qualify the care provided and/or make changes in their habits, to avoid experiencing a similar condition in the future ${ }^{(10)}$. In this direction, a multicenter study with a qualitative approach, conducted in three Italian cities with 32 patients and 44 nurses, explored the experiences of patients with advanced cancer and their nurse caregivers about care dependence and concluded that the relationship of caring for the other implies personal maturation, both for those who care and for those who receive care ${ }^{(11)}$.

Thus, the care process, associated with living in constant interaction with others and sharing life experiences, can result in the establishment of new beliefs and meanings to the health-disease process. This is because the meanings are formed in an attempt to make sense of the reality experienced and can influence the way in which care is offered, both for oneself and for the other ${ }^{(12)}$.

Given the above, there is a predominance of studies in the literature that address the negative aspects and the burden resulting from care. However, although to a lesser extent, it is possible that caregivers also experience positive meanings, and this possibility needs to be investigated/explored, including to support the performance of health professionals towards caregivers. Thus, the following question arises: Does care for the senile elderly influence the meaning that the caregiver attributes to aging?

It is believed that planning care actions aimed at caregivers of the elderly, especially in the context of Primary Care, based on knowledge of the different forms and meanings they attribute to the aging/illness process, can contribute to the establishment of more effective interventions care for this population.

\section{OBJECTIVES}

To understand the meaning of aging for caregivers of senile elderly people.

\section{METHODS}

\section{Ethical aspects}

After authorization from the Health Secretariat of the municipality in which the study was developed, the research was approved by the Research Ethics Committee Involving Human Beings, at the Federal University of Mato Grosso do Sul (CEP/ UFMS). All participants were informed about the purpose of the study and data collection procedures; and signed the Free and Informed Consent Form in two copies of equal content.

\section{Theoretical-methodological framework}

For the elaboration and description of the method, the guidelines of the Consolidated Criteria for Reporting Qualitative Research (COREQ) were taken into account.

The research was developed based on the theoretical precepts of medical anthropology, based on Kleinman's Explanatory Model of Disease, according to which the understanding and interpretation of the disease is a symbolic construction process. It occurs within a context influenced by intrinsic and extrinsic issues to the individual, sociocultural, and the search for treatment and cure involves different social actors in constant interaction ${ }^{(13)}$

According to this model, the provision of care comprises four subsystems: informal, family, popular and professional, which interact continuously with each other, allowing the individual to interpret their condition, signify and re-signify the health-disease process experienced and, in relation to consequently, to change attitudes, beliefs and behaviors. Thus, considering that health behaviors are centered on people's meanings and experience, it constitutes a challenge for health professionals to offer care that is closer to/consistent with these meanings $\mathrm{s}^{(13)}$.

It should be noted that the use of this framework in the analysis of the data allowed us to understand how the experience in the process of caring for a senile elderly person can influence the meanings attributed by the caregiver in relation to aging.

\section{Study type}

Descriptive study with a qualitative approach.

\section{Study scenario}

The research was carried out with caregivers of elderly people registered in a Home Care Service (SAD) of a state public hospital in the Midwest Region of Brazil. The service has two Multiprofessional Home Care Teams (EMAD) and a Multi-professional Support Team (EMAP), which are responsible for the three types of home care: Home Care 1 (HC1) - assists users who need less complex care; Home Care 2 ( $\mathrm{HC2}$ ) - serves individuals who need frequent care and more health resources; and Home Care 3 
(HC3) - aimed at individuals who need equipment(s) and/or procedure(s) of greater complexity ${ }^{(14)}$.

\section{Data source}

The participants in this study were caregivers for the elderly registered in $\mathrm{HC} 2$ and $\mathrm{HC}$. To do so, initially, a list was requested containing the records of the 22 elderly people being monitored by the multidisciplinary team of the SAD (modalities HC2 and HC3) and the telephone contact of the respective registered caregivers.

Inclusion criteria were considered: being 18 years old or older; and be in the role of caregiver, formal or informal, for at least six months. In turn, those not located by telephone contact were excluded for scheduling the interview, after three attempts on alternate days and times.

After identifying the possible participants, the coordination of the SAD team was asked to disclose the study to the caregivers and the orientation that one of the researchers would make telephone contact in order to explain about the study, make the invitation and later schedule the interview to those who agreed to participate.

A total of 16 caregivers met the pre-established criteria, however 1 did not accept to participate and 3 were excluded due to the impossibility of access due to outdated telephone contact. Thus, 12 caregivers were included in the study, with 4 caregivers of the elderly in the $\mathrm{HC} 2$ modality and 8 in the $\mathrm{HC} 3$.

\section{Data collection and data organization}

Data were collected from April to June 2019, at the caregiver's home, through semi-structured, individual interviews, recorded on digital media. They lasted an average of 50 minutes; and, in its course, an instrument consisting of two parts was used. The first had questions of characterization of the caregiver and the elderly; and the second presented three guiding questions: 1. What do you think Mr/Mrs/Miss NAME OF THE ELDERLY PERSON could have done to age differently? 2. Talk about what you think is necessary to age well. 3 . How do you perceive aging based on the assumed caregiver role?

All interviews were conducted by the main researcher, nurse, master's student in nursing with experience in collecting qualitative data, who had no previous contact with any of the study participants.

To preserve the identity of the participants, the interviews were identified by using the letter $E$ (interviewee) next to the number indicating the order in which they occurred, with the addition of the name of the link with the elderly and the age of the caregiver (eg.:E7, son, 47 years old). Data saturation was based on the exhaustive analysis of all interviews conducted and the achievement of the general objective.

\section{Data analysis}

The data were submitted to thematic content analysis, using the three established steps ${ }^{(15)}$. In the pre-analysis, a thorough and exhaustive reading of the transcribed content was performed. Then, in the material exploration stage, thematic areas were identified using codes, which were subsequently organized according to the identification of the meaning nuclei, namely: aging associated with the absence of disease; conditions and behaviors that influence aging; desire to age independently; unexpected changes in the course of life; aging associated with care dependence and reduced autonomy.

Finally, in the stage of treatment of the results, the cores of meaning were grouped according to their similarities and differences, with the main theme emerging, "Experiences that mean and re-signify aging", consisting of two categories: "Aging well depends on a lot of thing "and"Things changed after I started taking care".

It was not possible to validate the data with the participants. However, the data analysis carried out by the main researcher was validated by two other researchers, who, independently/ individually, read the reports and their analysis in depth; in cases of divergent interpretations, they discussed and validated only when the same meaning was recognized by two or by the three researchers.

\section{RESULTS}

Of the 12 elderly caregivers, 8 were female, 7 married, 4 single and 1 divorced. The average age was 46 years old (minimum of 32 and maximum of 59 years), and eight of them had completed high school; three, incomplete; and one, complete elementary school. All were informal caregivers, being a husband, a wife, nine children and a friend, and declared to follow a religion. Health condition: seven reported problems of respiratory origin; three had high blood pressure; one, musculoskeletal disorder; and one, breast cancer.

The 12 elderly people, dependent on care had an average age of 74 years (minimum of 60 years and maximum of 92 years) and 10 were female. Education: nine had incomplete primary education; one, complete high school; one, incomplete higher education; and one was illiterate. Lifelong occupation: six performed activities at home; two were cleaning assistants; one, maid; one, seamstress; one, real estate agent; and a trucker.

The most frequent chronic diseases were chronic obstructive disease (COPD) (seven cases), systemic arterial hypertension $(\mathrm{SAH})$, stroke, sequelae (five cases), in addition to concomitant inflammatory, rheumatic, and neurodegenerative problems.

\section{Getting old well depends on many factors.}

In the speech of the participants, factors that, in their perspective, influence senility were highlighted. According to caregivers, these factors are related to the elderly life trajectory. In other words, understanding better aging depends on opportunities and access to knowledge and information.

To age well depends on a lot. Things he didn't have [...]. Maybe if he had a better education, time to take care of himself, he could have a better old age. (E1, daughter, 42 years old)

To age well, it depends on the situation of the person, the family, as you are born, grow and develop, you study, you don't work as much. So, this influences a lot on your aging [...]. (E12, son, 59 years old) 
They also highlighted the occupation of the elderly, as an influential element in the adoption or not of care actions throughout their life trajectory.

Poor woman! Her life was very bad. She was born in the country, worked since she was a child in the fields, then married early [...] and always working. So, her life would have to have changed since early to be able to age well [...]. (E7, son, 57 years old)

[...] Being a truck driver is difficult. They nail their ass in that truck and don't 'get out' anymore! [...] How will you take care of yourself like that? She lives on the road all her life and needs to work [...]. (E10, daughter, 37 years old)

In addition, the behaviors adopted - such as unhealthy eating, physical inactivity and smoking, neglect for seeking medical care and adequate treatment - were identified as influencing the current health condition of the elderly. In addition, they reported that such behaviors are influenced by the perception of the health-disease process that the elderly person had throughout life and directly reflect on senility.

She neglected. Turns and moves she had a urinary tract infection and treated at home: "Ah, I'm not going to the doctor, I'm going to treat at home". (E3, informal caregiver, 46 years old)

She never wanted to do any exercise, she said she didn't have time. This lack of physical activity helped her to be sick and in the state she is in today. (E5, daughter, 51 years old)

Food helps a lot. The relatives who are older, on the farm, managed to live a long time, no one died new or became ill, 70, 80 years, due to the food they had. In the city, things have changed: there are industrialized foods and pollution, I take a lot for my son, who is 8 years old and has a great history of health problems. (E9, daughter, 32 years old)

The only thing she did wrong was smoking, from adolescence, until a year and a half ago. (E11, husband, 49 years old)

\section{Things changed after I started taking care}

It was evidenced in the reports that experiencing care for a senile elderly person leads the caregiver to reflect on aging and, sometimes, culminates in some reframing in order to achieve healthy aging.

[...] I took care of my mother who had Alzheimer's too, so I try to exercise and read a lot. I try to exercise my mind a lot, to have the healthiest habits so that I can age with more health [...]. I like my mind active, not dispersed, because I am very afraid of getting sick. (E3, informal caregiver, 46 years old)

A more detailed look at aging comes to mind. A look like "things change", I feel that a little bit; I need to take more care of myself. Care that previously went unnoticed, you start to be more attentive. Like, visits to the doctor, exams, physical activity, but what I found most important in that time is the "brake on the emotional area", the brake is detachment, letting go, letting go of the problems, you respect its limitations. I learned this by being a caregiver. (E8, wife, 57 years old)
We acquire life experience; we see things happen to each other and we learn from it. You miss something, tomorrow you will use this error to get it right. You see others making mistakes and see that it is not good for us. (E11, husband, 49 years old)

This process of experiencing senility through caring for others and reflecting on aging itself, sometimes provided a new meaning for self-care actions.

Today I am taking the right drugs, I went to the ophthalmologist, the eye pressure is good [...]. (E7, son, 57 years old)

He was always very stubborn. He had an appointment and he always postponed it, so I keep thinking like this: I am the main one, my life is up to me, I have to take care of myself, I will not be postponing. That other things explode, for me it is a pain of I don't know how many years I can avoid. We start to see that that young thing that we think has "that there's always going to be time", leaves it for tomorrow, and tomorrow may not exist because our time is today. But I ended up experiencing what it means to choose to live in the moment. For me to be fine tomorrow, I need to take care of mine today. Today I have to look at myself, to take care, to have wisdom to solve things, so that way, we change these concepts of life. (E8, wife, 57 years old)

After I saw her like this, I started to sleep well, eat well, I make no effort, so extravagance to get hurt. I don't drink, I don't smoke. (E11, husband, 49 years old)

And, also, it made caregivers signify their own aging and highlight the way they want to grow old.

[...] you need to know how to deal with the things that happen to you, both in terms of physical limitations, you have to be aware that you will grow old and that you will be more restricted in some things. But you have to be fine. You have to learn to understand, to deal with yourself, that is to have wisdom, without isolating yourself from the world, being the best within your limitations. (E8, wife, 57 years old)

[...] I want to see if I can get old on the job and, even after I am retired, I want to look for something to do, so I can always work. I don't want to stop, stay still, no. (E12, son, 59 years old)

However, senility was negative and constituted a condition that excludes, from the perspective of caregivers, the possibility of aging well.

Aging in the disease is not good. Being healthy, you are not dependent on others, you can automatically do your thing and live well. (E2, daughter, 40 years old)

In order to age well, you cannot have a disease, or diabetes, any pressure disease, or have to undergo any treatment [...]. (E6, daughter 48 years old)

Aging well is that you are active in everything and have no problem with heart health, lungs. (E10, daughter 37 years old)

She is a lucid person, she knows everything, but she wants to go to the bathroom quickly to take a shower, she can't do it, she has 
to help her. She can't come and make the food she would like to make, we have to make it for her. This aging with disease is negative. (E11, husband, 49 years old)

\section{DISCUSSION}

Aging, although it is a phase of the life cycle inherent to human beings, is influenced by individual factors, such as genetic characteristics, behaviors adopted throughout life and external factors (economic, political, environmental, and social aspects) ${ }^{(10)}$. In this sense, the results of the present study show that participating caregivers mean aging according to the life history and behaviors adopted by individuals in all its stages, which corroborates the central concepts of the adopted theoretical framework - the Kleiman's Explanatory Disease Model ${ }^{(13)}$.

In their perception, elderly people who, in their youth or even as adults, did not have many opportunities for life or access to formal education, for example, may have more difficulty accessing knowledge and also understanding health information and, therefore, greater limitations in the adoption of self-care behaviors, triggering the occurrence of senile aging. This thinking, in addition to being part of common sense, is reinforced by studies according to which literacy positively influences self-care, and the higher the level of education, the greater the search for and access to health services ${ }^{(16-17)}$.

Some participants pointed out that the rural context in which the elderly grew up proved to be an unfavorable factor for them to have a healthy aging today, because people started to work "hard" very early, and this work did not allow them to take care of themselves. Even today, despite all technological advances, studies show that the place of residence can limit access to health services and information ${ }^{(17-18)}$. Furthermore, it is worth considering that living in this context nowadays may even have an impact on self-perceived health, as identified in a study with elderly people living in different locations, which pointed out that, among those in the rural area, the prevalence of regular perception or bad is higher than among residents in the urban area ${ }^{(18)}$.

It is important to highlight that some caregivers emphasized the quality of food that today's elderly people had in childhood and youth, especially when they lived in rural areas. However, it seems that the eating habits of yore are not always followed, as currently the non-adoption of healthy eating by people (mostly elderly) with chronic diseases such as high blood pressure and diabetes mellitus is a great challenge for the health sector.

Unhealthy behaviors that can influence senility were also indicated by the caregivers participating in this study. According to them, certain habits such as smoking, physical inactivity, inadequate nutrition, neglect of treatment and absence of seeking medical care expose individuals to the development of chronic conditions and future complications, which negatively impacts aging. A similar result was found in a cross-sectional study conducted with 1,546 families living in a community in the city of São Paulo ${ }^{(19)}$.

It was observed that the inadequate lifestyle habits, pointed out by the caregivers, were influenced by the concept of healthdisease, and directly reflect on the perception of aging. It should be noted that cultural characteristics, marked by different times, customs and societies, can also influence the behaviors adopted and the meaning attributed to aging, according to the theoretical framework adopted ${ }^{(13)}$. These aspects reinforce the need to include caregivers when planning assistance for elderly senile people, and even investigate factors related to their own life history and experiences that can influence their perceptions of the health-disease process and the meaning of aging. This is because these factors may reflect the adoption of different care actions with oneself and with the elderly person for whose care he is responsible.

Furthermore, in the perception of the caregivers participating in this study, culture and society can also influence the adoption of inappropriate eating habits and, therefore, senile aging, which corroborates the results of an ethnographic study carried out in a Social Coexistence Center in Pelotas, RS, which pointed out that family influence, social aspects and regional culture interfered in the choice and consumption of food ${ }^{(20)}$. Food choices can be interpreted differently by individuals who are in different cultures, contexts, and stages of the life cycle, which, according to the Explanatory Disease Model, makes the recognition of peculiarities by health professionals predominant, with a view to planning care actions and changing habits.

In this sense, the meanings attributed by the experience and experience of caring can contribute to the reflection of caregivers of senile elderly people about the relationship between healthrelated behaviors and habits assumed throughout life and their influence on aging, allowing a new meaning of this process. This, in turn, can help health professionals to raise awareness of caregivers and implement strategies and actions that favor the development of healthy behaviors and lifestyle habits.

Regarding the meanings attributed to aging, it was observed that the experiences throughout the care process for the elderly led caregivers to reflect on their own aging and on possible alternatives for this process to be healthier. This is confirmed when it is found that taking care of a senile elderly person aroused the interest in starting or even the need to continue self-care actions, characterized, for example, by carrying out routine medical consultations and regular physical activity. This fact allows us to infer that such an experience may constitute a protective factor for the development and / or complication of chronic diseases. In turn, knowing the perceptions and meanings attributed by the caregiver to this experience can support professionals in proposing self-care actions and behavior changes for this audience.

It is emphasized that the habit of taking care of oneself must accompany the individual since youth, but this is not a recurring practice ${ }^{(21)}$. However, the neglect of self-care is a risky behavior assumed throughout life that creates conditions for senility, since the cumulative attitude of abstaining from everyday problems and of not valuing one's own needs tends to cause damage to health. Thus, although sometimes the focus of the person who makes the commitment to take care of the other is the performance of this function, it is important that health professionals use all opportunities for contact/interaction with the caregiver to encourage the adoption of self-care actions and to help you develop strategies that consider your particularities, needs and possibilities. Such strategies, according to the adopted framework, can be initiated through the survey of care actions that these 
caregivers already perform in relation to their own health, as well as those that they believe to be important.

This is particularly relevant in the case of caregivers of senile elderly people, as care for them is often strenuous. A study carried out with 18 family caregivers of individuals with chronic illnesses linked to the SAD of a hospital in the Southern Region of Brazil pointed out that caring too much for others, sometimes, causes a neglected look at themselves regarding their personal needs ${ }^{(22)}$.

The experience of caring also gave a new meaning to their practices, in addition to changing their behavior in the face of what was called "other people's mistakes", represented by unhealthy health behaviors adopted throughout life. In this sense, current limitations are identified as consequences of abusive habits throughout life, and this perception, in turn, favors the adoption of actions such as reducing alcohol consumption, smoking cessation and starting to practice physical activity ${ }^{(23-27)}$. A comprehensive approach study, which aimed to understand family experience in modeling care based on the reinterpretations of everyday life, also identified several situations that transformed existing vulnerabilities into potentialities for care ${ }^{(23)}$. This shows not only that care is shaped over time, but also the importance of health professionals getting closer to people's experiences and proposing care practices that value not only the needs, but also the possibilities of people to implement them.

In Sweden, elderly men participating in a study on how to achieve "good old age" asserted that self-awareness and daily reflection on aging directly affect the way they operate the experiences of that phase. Thus, they are active agents involved in maintaining meaning and satisfaction with life, which directly influences the ability to manage changes over time ${ }^{(28)}$.

The participants' reports show that, from the experience of taking care of the other, being this senile, reflections about the attitudes of caring for oneself arose, which confirms the results of a study carried out in Rio de Janeiro-RJ, which sought to understand the new ways of living and relating goers old House of Natural Therapies and Body Practices (CTNPC) ${ }^{(29)}$. The results of this study showed, for example, that for some, reaching older age is synonymous with retirement and tranquility; for others, it is the moment of dedication to self-care, with new meanings of identity ${ }^{(29)}$. Therefore, when experiencing care for others, sometimes the caregiver refreshes pre-established concepts, habits, and behaviors, and this can contribute to changing their behavior in relation to health. In this sense, some actions can be taken to avoid stagnation in the old age phase, such as maintaining social coexistence, developing self-awareness and not giving value to the stereotypes of the elderly, often linked to a disabling condition ${ }^{(29)}$.

Finally, it is worth noting that the study participants emphasized the desire not to have senile aging, as they recognize the association of illness with a negative experience of this stage of life, as identified among family members of the elderly in a Community Center who related this condition to a stage marked by restrictions and dependence ${ }^{(10)}$. In view of this, the need for actions to demystify this relationship as something natural is emphasized, since there are countless behaviors that can be modified throughout life and reflect positively on aging. Furthermore, it is noted that the positive perception of aging can favor individual satisfaction, as pointed out in a study carried out with elderly Argentines ${ }^{(30)}$.

Thus, it is seen that professionals working in Primary Care have an important role in relation to the development of prevention and control actions for chronic diseases to improve the quality of life, especially regarding the particularities of the caregiver's routine. Therefore, it is necessary for the health professional to be attentive to the caregiver in relation to their habits of life and self-care, rescuing and valuing beliefs that favor the quality of life and reviewing those that may compromise it. The use of brief interventions, such as the motivational interview, which can be carried out during the nursing consultation or even in the care of senile elderly people, either in health services (hospitals and basic units), or at home, can contribute to this process.

Still, these care actions, in order to be coherent with the Kleinman's Explanatory Model of Disease, need to go beyond the predominant consideration of physical aspects related to the existence of diseases, in order to enable the professional's understanding of the experiences, anxieties and anxieties in the face of aging. With this information in place, the team has subsidies to understand the meanings attributed (social, individual and family) related to senility, which can direct care in order to favor the reframing, which, in turn, can contribute to aging healthy.

\section{Study limitations}

Possible limitations of the study refer to the characteristics of qualitative studies, which do not allow generalizations or the establishment of a cause-and-effect relationship; and the fact that the data have not been validated by the participants. To minimize this limitation, the data analysis was validated by two other researchers. Finally, studies that address caregivers of the elderly with other sociodemographic and health characteristics and/or that adopt triangulation in data collection may expand and enhance the results found.

\section{Contributions to the field of nursing, health, or Public Policy}

In the search for understanding the meaning of aging for caregivers of senile elderly people, aspects that were modifiable and non-modifiable that could influence healthy aging were identified. Furthermore, the experience of caring reflected on the reflection of these individuals on their own aging, as well as on the reframing of some adopted behaviors.

The results of this study can support reflections on the part of health professionals about the importance of including the caregiver in the planning of care that is provided to the elderly and other people dependent on care. The need to offer visibility to these caregivers and to include them in the care actions planned by the health team is highlighted, including offering alternative hours that allow them to participate in the proposed activities.

The study also highlighted the influence of the experience of carrying out care, beliefs and meanings in the perception of aging, which allows health professionals, especially nurses, to identify modifiable factors that can be considered in care planning to that audience. 


\section{FINAL CONSIDERATIONS}

With the results, it was possible to understand that caregivers mean aging based on their experiences in the face of the assumed role, especially associating it with the presence of chronic disease and dependence on care. In other words, the experience of caring for senile elderly people allows the identification of aspects and modifiable and non-modifiable behaviors that influence healthy aging, providing reflection in relation to aging itself, as well as the reframing of habits and behaviors that can be adopted with a view to favor your own life, health, and aging.

Thus, the findings of this study can help FHS nurses to promote care actions that also address the caregiver's health, considering their perceptions and particularities related to the routine and care activities. They will be able, for example, to accompany the elderly who receive home care, to agree goals related to health behaviors that also make it possible to include caregivers.

Furthermore, it is suggested that future studies be carried out, in particular intervention, in order to test different strategies that contribute to self-care actions among caregivers, expanding care to the caregiver/elderly binomial.

\section{FUNDING}

This work was carried out with the support of the Universidade Federal de Mato Grosso do Sul - UFMS and the Coordination of Improvement of Higher Education Personnel - Brazil (CAPES) Funding Code 001.

\section{REFERENCES}

1. Miranda GMD, Mendes ACG, Silva ALA. O envelhecimento populacional brasileiro: desafios e consequências sociais atuais e futuras. Rev Bras Geriatr Gerontol. 2016;19(3):507-19. https://doi.org/10.1590/1809-98232016019.150140

2. Sousa RB. A Atenção domiciliar na desospitalização de pacientes. Rev Científ Esc Est Saúde Pública [Internet]. 2018 [cited 2019 Oct 20];4(2):102-13. Available from: http://www.revista.esap.go.gov.br/index.php/resap/article/view/78/100

3. Ministério da Saúde (BR). Caderno de Atenção Domiciliar. Brasília: MS; 2012. 106p.

4. Arenella K, Steffen AM. Self-reassurance and self-efficacy for controlling upsetting thoughts predict depression, anxiety, and perceived stress in help-seeking female family caregivers. Int Psychogeriatr. 2019;32(2):229-40. https://doi.org/10.1017/S1041610219000565

5. Bangerter LR, Liu Y, Zarit SH. Longitudinal trajectories of subjective care stressors: the role of personal, dyadic, and family resources. Aging Mental Health. 2019;23(2):255-62. https://doi.org/10.1080/13607863.2017.1402292

6. Padovani C, Lopes MCL,Higahashi IH, Pelloso SM, Paiano M, Christophoro R. Being caregiver of people with Parkinson's Disease: experienced situations. Rev Bras Enferm. 2018;71(suppl 6):2628-63. https://doi.org/10.1590/0034-7167-2017-0008

7. Cunha JVB, Reiners AAO, Azevedo RCS, Cardoso JDC, Cunha CRT, Silva KM. Functioning of families with fully dependent elderly. Ciênc Cuid Saúde. 2019;18(2):e48825. https://doi.org/10.4025/cienccuidsaude.v18i2.48825

8. Faria EBA, Scardoelli MG, Castro VC, Nishida FS. Experiences of family caregivers of elderly with Alzheimer's Disease. Ciênc Cuid Saúde. 2017;16(1). https://doi.org/10.4025/cienccuidsaude.v16i1.31004

9. Krutter S, Schaffler-Schaden D, Essl-Maurer R, Wurm L, Seymer A, Kriechmayr C, et al. Comparing perspectives of family caregivers and healthcare professionals regarding caregiver burden in dementia care: results of a mixed methods study in a rural setting. Age Ageing. 2019; 49(2):199-207. https://doi.org/10.1093/ageing/afz165

10. Colussi EL, Pichler NA, Grochot L. Percepções de idosos e familiares acerca do envelhecimento. Rev Bras Geriatr Gerontol. 2019; 22(1)1-8. https://doi.org/10.1590/1981-22562019022.180157

11. Candela ML, Piredda M, Marchetti A, Fachinetti G, lacorassi A, Capuzzo MT, et al. Finding meaning in life: an exploration on the experiences with dependence on care of patients with advanced cancer and nurses caring for them. Support Care Cancer. 2020; 28:4493-99. https://doi. org/10.1007/s00520-020-05300-8

12. Wright LM, Bell JM. Beliefs and illness: a model for healing. Canada: 4th Floor Press, 2009. 385 p.

13. Kleinman A. The illness narratives: suffering, healing and the human condition. New York; 1988. 284p.

14. Ministério da Saúde (BR). Portaria no 825, de 25 de abril de 2016. Diário Oficial da União, 26 de abril de 2016. P. 33.

15. Bardin L. Análise de conteúdo. São Paulo: Edições 70; 2016.

16. Nicolato FV, Santos CM, Castro EAB. Autocuidado e vivências do envelhecer de cuidadores familiares de idosos: contribuições para enfermagem gerontológica. Tempus Actas Saúde Coletiva.2017;11(1):169-86. https://doi.org/10.18569/tempus.v11i1.2050

17. Melo LA, Braga LC, Leite FPP, Bittar BF, Oséas JMF, Lima KC. Fatores associados à multimorbidade em idosos: uma revisão integrativa da literatura. Rev Bras Geriatr Gerontol. 2019;22(1):1-11. https://doi.org/10.1590/1981-22562019022.180154

18. Macedo E, Ulrich B, Bós AMG, Bós AJG. Fatores relacionados à autopercepção do estado de saúde em idosos residentes no meio rural do Brasil. Scientica Medica. 2018; 28(3):ID29698. https://doi.org/10.15448/1980-6108.2018.3.29698

19. Oliveira NC, Portes LA, Zukowosky-Tavares C, Martins LT, Bonito J. Tabagismo e estilo de vida em área de vulnerabilidade social. Revista Família Ciclos de Vida e Saúde no contexto social. 2018;6(supl.1):306-11. https://doi.org/10.18554/refacs.v6i0.2908 
20. Martin RM, Lindemann IL, Oliveira RC. Consumo alimentar e uso de preparações regionais por pessoas idosas: um estudo qualitativo. Rev Kairós: Gerontol. 2018; 21(2):193-213. https://doi.org/10.23925/2176-901X.2018v21i2p193-213

21. Ribeiro MS, Cendoroglo MS, Lemos NFD. A percepção dos idosos acerca de seus hábitos de vida e comportamento de autocuidado quando jovens e a influência destes na saúde e envelhecimento. Rev Kairós: Gerontol. 2015;18(2):81-101. https://doi. org/10.23925/2176-901X.2015v18i2p81-101

22. Ribeiro BF, Oliveira SG, Tristão FS, Santos-Jr JRG, Farias TA. Práticas de si de cuidadores familiares na atenção domiciliar. Rev Cuid. 2017;8(3):1809-25. https://doi.org/10.15649/cuidarte.v8i3.429

23. Barbosa MRC, Souza IP, Souza SPS. Ressignificações do vivido em família e o movimento transformador na modelagem do cuidado. Ciênc Cuid Saúde. 2018;17(1). https://doi.org/10. 4025/cienccuidsaude.v17i1.38092

24. Heger I, Deckers K, Boxtel M, Vugt M, Hajema K, Verhey F, et al. Dementia awareness and risk perception in middle-aged and older individuals: baseline results of the Mijn Breincoach survey on the association between lifestyle and brain health. BMC public health. 2019;19(1):678. https://doi.org/10.1186/s12889-019-7010-z

25. Moraes G, Giacomin K, Santos WJ, Firmo JOA. A percepção dos idosos sobre o saber biomédico no cuidado à velhice e às " coisas da idade". Physis: Rev Saúde Coletiva. 2016;26(1):309-29. https://doi.org/10.1590/S0103-73312016000100017

26. Adms ML, Grandpre J, Katz DL, Shenson D. The impact of key modifiable risk factors on leading chronic conditions. Prev Med. 2019;120:1138. https://doi.org/10.1016/j.ypmed.2019.01.006

27. Kojima G, Avgerinou C, lliffe S, Walters K. Adherence to Mediterranean diet reduces incident frailty risk: systematic review and metaanalysis. J Am Geriatrics Soc. 2018;66(4):783-8. https://doi.org/10.1111/jgs.15251

28. Carstensen G, Rosberg B, McKee KJ, Aberg AC. Before evening falls: perspectives of a good old age and healthy ageing among oldest-old Swedish men. Arch Gerontol Geriatr. 2019; 82:35-44. https://doi.org/10.1016/j.archger.2019.01.002

29. Camargo TC, Telles SDCC, Souza CTA. A (re)invenção do cotidiano no envelhecimento pelas práticas corporais e integrativas: escolhas possíveis, responsabilização e autocuidado. Cad Bras Ter Ocup. 2018;26(2):367-80. https://doi.org/10.4322/2526-8910.ctoAO1238

30. Acosta LD. Factores asociados a la satisfacción vital en una muestra representativa de personas mayores de Argentina. Hacia Promoc Salud, 2019;24(1):56-69. https://doi.org/10.17151/hpsal.2019.24.1.6 